\title{
Evde Bakım Hizmetlerinin Almanya ve Türkiye Örneğinde Karşılaştırılması: Nitel Bir Araştırma*
}

\author{
Comparıson of Home Care Services in The Case of Germany and Turkey: A Qualitative \\ Research
}

\author{
Mustafa ÇOBAN ${ }^{+*}$ \\ DD0000-0002-3071-8385
}

\author{
Afsun Ezel ESATOĞLU*
}

0000-0002-0542-7228

\section{MAKALE BILLISİ}

Başvuru: 16.10.2021

Düzeltme Talebi: 26.10 .2021

Son Düzeltme: 27.10.2021

Kabul: 07.12.2021

Online Yayım: 15.12.2021

\section{Anahtar Kelimeler:}

Sağlık Yönetimi Evde Bakım Hizmetleri Sosyal Politika Uzun Dönem Bakım Avrupa Çalışmaları
ÖZ

Bakım hizmetlerine olan gereksinimin artması ile birlikte evde bakım hizmetlerine olan talebi artmıștır. Bu çalıșmada evde bakım sistemini bakım sigortası ile bütünleștiren ve Türkiye Cumhuriyeti kökenli kişilerin Türkiye dıșında en fazla yașadığı ülke olan Almanya ile Türkiye'deki evde bakım hizmetleri incelenmiștir. Araştırma, Almanya $(n=10)$ ve Türkiye'de (n=13) evde bakım hizmetleri yöneticileriyle yarı yapılandırılmış görüşme formu kullanılarak gerçekleştirilmiştir. Almanya'daki görüşmeciler, evde bakım hizmetlerinin sunumunda pazarlama sürecinde yoğun bir rekabetin yaşandığını, bakım planları ve standartları uygulamanın güçlügü, sigorta șirketlerinin maliyetleri düşürmek odaklı yaklaşım içerisinde olduklarını, denetim sürecinde bürokratik işlemlere odaklanıldığını belirtmişlerdir. Türkiye'de, sağlık ve sosyal bakım uygulamalarının farklı kurumlar tarafından yönetilmesi, evde bakım hizmetlerinin de denetim eksikliği, haksız rekabeti düzenleyici uygulamaların yetersiz olması temel sorunlar olarak belirtilmiştir. Türkiye evde bakım hizmetlerinin tanımı, kapsamı gibi birçok konuda uzlaşım bulunmazken Almanya'da bu bir sorun olarak yer almamıștır.

\section{A B S T RACT}

With the increase in the need for care services, the demand for home care services has increased. In this study, home care services in Germany, where most of the Turkish origin people abroad live, and Turkey, which integrate the home care system with the care insurance were examined. The research was conducted using a semi-structured interview form with home care service managers in Germany $(n=10)$ and Turkey $(n=13)$. Interviewees in Germany stated that there is intense competition in the marketing process in the delivery of home care services, it is difficult to implement care plans and standards, insurance companies are focused on reducing costs, and bureaucratic procedures are focused on during the audit process. In Turkey, the management of health and social care practices by different institutions, the lack of supervision in home care services, and the inadequate regulatory practices of unfair competition are stated as the main problems. While there is no consensus on many issues such as the definition and scope of home care services in Turkey, this has not been stated as a problem in Germany. 


\section{$1 \quad$ Giris}

Bireylerin bakım hizmetlerine olan gereksinimin artması ile birlikte artan talebi karşılamaya yönelik farklı dinamikler ve bakım modelleri gelişmiştir. Evde bakım hizmetleri de artan bakım gereksinimine karşllk gelișen hizmet sunum modellerinden biridir (DePalma, 2008; Genet vd., 2012; Jones, 2014; Shang ve Wu, 2011; Weissert vd., 2005). Evde bakım hizmetlerinin birçok ülkede birbiriyle etkileşim içerisinde sağlık ve sosyal hizmet modeli olarak uygulandığı izlenmektedir (Gupta, 2013; Arita ve Ryu, 2013; Nadash vd., 2012; Santana, 2010, Schmid, 2005).

Evde bakım hizmetleri birçok ülkede yaygın bir şekilde kullanılmasına rağmen uzlaşım sağlanmıș tanım ve kapsam bulunmamaktadır. Sunulan hizmetin içeriği, kimler tarafından kime verildiği, evde bakım hizmetleri tanımlarında farklılık gösteren temel ögeler iken ortaklaştığı temel nokta kişiye evinde sağlık ve sosyal hizmet sunulmasıdır (Bentur, 2001; Davis, 1994; Genet, Kroneman, Boerma 2013; Littauer, 1960; Living Indepently at Home [Livindhome], 2011; Ryder, Stitt Pauline ve William, 1969; Thome, Dykes ve Hallberg, 2003); (Bentur, 2001; Genet ve diğerleri, 2012:9; Kersktra ve Hutten, 1996; Ryder ve diğerleri, 1969; ve diğerleri, 2003), 15 Avrupa Birliğił (AB) ülkesinde yaptıkları bir çalışmada, evde bakım hizmetlerinden "ne anlaşılması" gerektiği konusunda $A B$ ülkeleri arasında da bir uzlaşım olmadığını belirmişlerdir. $A B$ ülkelerinde Ortak bir tanımın olmamasının bir sonucu olarak üye ülkelerde ortak bir sağlık sunumunu hedefleyen "sınırlar ötesi sağlık hizmetleri sunumu direktifinde" uzun dönem bakım hizmetlerinin bir parçası olan evde bakım hizmetleri kapsam dışı bırakılmıştır. $B u$ tanımın ve içeriğinin belirsizliği $A B$ vatandaşlarının $A B$ ülkelerinde ortak bir evde bakım hizmeti almasını engelleyen durumlardan bir tanesi olarak değerlendirilmektedir (European Union [EU], 2008, 2011).

Türkiye'de de Başbakanlık Devlet Planlama Teşkilatı tarafından hazırlanan Birinci Kalkınma Planı'nda (Resmî Gazete [RG], 1963), evde bakım hizmetleri, yataklı tedavi hizmetlerinin bir alternatifi ve sağlı hizmetlerinin yaygınlaştırılması ve maliyetin azaltılması için bir araç olarak görülmektedir. Kalkınma planında, evde bakım hizmetleri örgütlenmesinin geliştirilmesi ve evde bakım birimlerinin kurulması konusunda pilot bölge çalışmalarının yapılması önerilmekle birlikte, bu öneriler uygulamaya geçirilmemiştir. Ancak son yıllarda artan yaşlı nüfusa paralel olarak bakım hizmeti gereksiniminin artması, yaşanan toplumsal sosyo-ekonomik değişimler Türkiye'de de politika yapıcılarının ve özel sağlık kuruluşlarının evde bakım hizmetlerine olan ilgisini artırmış ve evde bakım hizmetleri ülke sağlık hizmetleri gündemine yeniden hızı biçimde tekrar girmiştir.

Evde bakım hizmetlerinin yeniden yapılanması sürecinde nitelikli bakım hizmetinin oluşturulması toplumsal refahın gerçekleștirilebilmesi için önemlidir. $\mathrm{Bu}$ makalede var olan durumun saptanabilmesi amacıyla Türkiye'deki şu an için sürdürülmekte olan evde bakım hizmetleri ile Almanya'da sürdürülen evde bakım hizmetlerinin karşılaştırılmasını içeren bir çalıșma planlanmıştır. Çalışma kapsamında Almanya'nın seçilmesinin nedenleri aşağıda yer almaktadır:

- $\quad$ Evde bakım hizmetlerinde kültürel ve kişisel değerler önemli bir yer tutmakta ve evde bakım hizmetlerinin işleyiş sürecine doğrudan etki etmektedir (Glodny vd., 2011; Lange vd., 2013; Lottmann vd., 2013). Bu nedenle evde bakım hizmetleri konusunda, Türkiye sınırları dışında, Türkiye toplumuna ait kültürel ve kişisel değerlerin evde bakım hizmetlerine olan etkisinin izlenebileceği, Türkiye Cumhuriyeti uyruklu nüfusun en çok yaşadığı ülke olan Almanya (Yurtdışı Türkler ve Akraba Topluluklar Başkanlığı, 2011:3) seçilmiştir,

- Türkiye'de son on yılda bir bakım sigortasının gerekli olduğuna ilişkin tartışmalarda ivmelenme bulunmaktadır (Oğlak, 2007; Tufan,2009). Almanya'nın bakım sigortasının gelişiminde büyük katkısı bulunması ve bu sigortanın ilk uygulayıcılarından biri olması seçim nedenlerinden bir diğeridir.

- $\quad$ Almanya, Türkiye'nin ekonomik ve sosyal ilişkileri açısından önemli partnerlerinden biridir (TÜİK, 2014; Dışişleri Bakanlığı, 2014) ve bu nedenle kurumların ve sektörlerin birbirini etkilemesi kaçınılmaz olup Almanya sağlı ve sosyal güvenlik sisteminin etkileri Türkiye için yüksektir.

\footnotetext{
*Araştırma yapılan ülkeler: Avusturya, Belçika, Danimarka, Finlandiya, Fransa, Almanya, Yunanistan, İrlanda, İtalya, Lüksemburg, Hollanda, Portekiz, İspanya, İsveç ve Birleşik Krallık.
} 
- $\quad$ Almanya'nın sosyal refah yasası kapsamında evde bakım hizmetlerine başladığı ilk dönemlerdeki (1960'lı yıllar) nüfus yapısı ile Türkiye'nin günümüz nüfus yapısı benzerlik göstermektedir (Federal Statistical Office of Germany, 2013: 11).

Evde bakım hizmetlerinin geliştiği bir ülke örneği ile henüz yeni yapılanmakta olan bir ülkenin karşılaştırılmasına dayalı bu çalışmanın, gelişmekte olan ülkelerdeki evde bakım sektörlerinin nitelikli olarak yapılanmasına katkı sağlayabileceği düşünülmektedir.

\subsection{Almanya'da Evde Bakım Sistemi}

Almanya sağlık sisteminin temelini, Alman Anayasası'nın özünde yer alan "İnsan onuruna dokunulmaz. Tüm devlet otoritesi, onu gözetmek ve korumakla yükümlüdür” hükmü oluşturur ve sağlık ve sosyal hizmetlere erișimdeki temel araçlardan biri de Almanya Sosyal Güvenlik Yasası'dır (Sozialgesetzbuch) (Heinicke ve Thomsen, 2010: 2). İlk bölümü genel hüküm olmak üzere 12 bölümden oluşan sosyal güvenlik yasanının içerisinde farklı bir sosyal güvenlik başlığı bulunmaktadır. Genelde SGB XI olarak adlandırılan "zorunlu uzun dönem bakım sigortası" ve SGB V biçiminde kısaltılan zorunlu sağlık sigortası bu yasanın içerisinde yer almaktadır (Çizelge 1) (https://www.sozialgesetzbuch-sgb.de/).

Tablo 1. Almanya Sosyal Güvenlik Kanunu'nun bölümleri

\begin{tabular}{|l|l|l|}
\hline KOD & Bölüm & \\
\hline SGB I & Genel hükümler & Allgemeiner Teil \\
\hline SGB II & İşsizlik sigortası & Grundsicherung für Arbeitsuchende \\
\hline SGB III & İstihdam geliştirici düzenlemeler & Arbeitsförderung \\
\hline SGB IV & Sosyal güvenlik için temel ilkeler & $\begin{array}{l}\text { Gemeinsame Vorschriften für die } \\
\text { Sozialversicherung }\end{array}$ \\
\hline SGB V & Zorunlu sağlık sigortası & Gesetzliche Krankenversicherung \\
\hline SGB VI & Zorunlu emeklilik sigortası & Gesetzliche Rentenversicherung \\
\hline $\begin{array}{l}\text { SGB } \\
\text { VII }\end{array}$ & Zorunlu kaza sigortası & Gesetzliche Unfallversicherung \\
\hline $\begin{array}{l}\text { SGB } \\
\text { VIII }\end{array}$ & Çocuk ve gençlik hizmetleri & Kinder- und Jugendhilfe \\
\hline SGB IX & $\begin{array}{l}\text { Engellilerin rehabilitasyonu ve } \\
\text { katılımı }\end{array}$ & $\begin{array}{l}\text { Rehabilitation und Teilhabe behinderter } \\
\text { Menschen }\end{array}$ \\
\hline SGB X & $\begin{array}{l}\text { Sosyal yönetim süreçleri ve sosyal veri } \\
\text { koruması }\end{array}$ & $\begin{array}{l}\text { Sozialverwaltungsverfahren und } \\
\text { Sozialdatenschutz }\end{array}$ \\
\hline SGB XI & Zorunlu uzun Dönem bakım sigortası & Soziale Pflegeversicherung \\
\hline $\begin{array}{l}\text { SGB } \\
\text { XII }\end{array}$ & Sosyal refahı geliştirici düzenlemeler & Sozialhilfe \\
\hline
\end{tabular}

Almanya'da uzun dönem bakım hizmetleri ilk defa 1962 yılında Federal Refah Yasası (Bundessozialhilfegesetz) içerisinde yer almış ve sosyal refahı geliştirici uygulamalardan biri olarak kabul edilmiştir. (Wiener ve Cuellar,1999). Almanya'da bakım hizmetleri ile ilgili reform çabaları içerisinde en köklü değişimi, Nisan 1994'te bakım sigortası (Soziale Pflegeversicherung) uzun dönem bakım bakım hizmetleri de kapsayacak biçimde sağlık sigortasından bağımsız olarak ayrı bir sigorta olarak yasalaşmıştır (Wiener ve Cuellar,1999).

Almanya'da bakım sigortası kapsamında; profesyonel olmayan bakım sağlayan kişiye verilen bakım parası, profesyonel evde bakım hizmetleri, kısmen ayakta bakım hizmetleri, engellilere yönelik özel hizmetler, kısa süreli bakım hizmetleri, yatılı bakım kurumlarında sağlanan hizmetler, bakım sağlayacak kişiye yönelik bakım kursları, bakım hizmetleri için gerekli araç ve gereç desteği, bakıma muhtaç kişinin yaşadığı mekân ve çevresinin kişinin yaşamını kolaylaştıracak şekilde düzenlenmesi olmak üzere dokuz temel başlıkta hizmet sunulmaktadır. Almanya'da bakım sigortası kapsamında yatılı bakım kurumlarından ve evde bakım hizmetlerinden yararlanma aşamalı olarak gerçekleşmiş 
evde bakım hizmetlerinden 1 Nisan 1995'ten itibaren, yatılı bakım hizmetlerinden ise 1 Temmuz 1996'dan itibaren yararlanabilmişlerdir.

Almanya'da kişilere, bakım gereksinimleri, bakım olanakları ölçüsünde kurumda bakım veya evde bakım hizmetlerini seçme hakkı tanınmaktadır. Kişi evde bakım hizmetleri tercih etmesi durumunda aile üyeleri ya da profesyonel olmayalar tarafından sağlanan evde bakım hizmetini veya profesyonel evde bakım kuruluşlarından sunulan evde bakım hizmeti olmak üzere temel olarak iki seçenekten birini seçme hakkına sahiptir. Almanya'da genellikle aile üyeleri tarafından verilen evde bakım hizmeti tercih edilmektedir (Statistisches Bundesamt, 2018:16). Kişilerin aile tarafından verilen informal bakım hizmetlerini tercih etmelerinde, aile üyelerine çalışma olanağı sağlaması, aile için bir gelir olarak görülmesi ve bakım hizmeti alan bireyin mahremiyetinin daha iyi korunabilmesine olanak sağlaması gibi nedenlerin rol oynadığı düşünülmektedir. Almanya'da 2017 yılında uzun dönem bakım sigortası kapsamında bakım hizmetlerinden 2017 yılında 3.414378 kişi (nüfusun \% 4ü) yararlanmıștır. Bakım hizmetlerinden yararlananların \%76'sı $(n=2.594 .862)$ evde bakım hizmetinden yararlanırken, geri kalan \%24'ü $(n=818.289)$ huzurevleri, hospice, gündüz bakım merkezleri gibi kurumda bakım hizmetlerinden yararlanmıştır. Evde bakım hizmetlerinden yararlananların \%68'i $(n=1.764 .904)$ aile fertleri tarafindan bakılmakta ve bakım sigortasından verdikleri hizmet karşllığında ücret almaktadırlar. Profesyonel evde bakım kuruluşlarından yararlananlar tüm evde bakım alanların \%32'si (n=829.958) (Statistisches Bundesamt, 2018:18). Evde bakım hizmeti alan kişilerin \%66'sı informal bakım alırken, \%34'ü profesyonel evde bakım kuruluşlarından hizmet almaktadırlar. İnformal bakım hizmeti alanlar tüm bakım hizmetlerinden yararlananların yaklaşık \%51'ini oluşturmaktadır (Statistisches Bundesamt, 2018: 18).

\subsection{Türkiye'de Evde Bakım Sistemi}

Türkiye'de evde bakım hizmetleri ile ilgili yasal düzenlemeler Sağlık Bakanlığı (SB) ve Aile ve Sosyal Hizmetler Bakanlığı (ASHB) tarafından yürütülmektedir. Ayrıca belediyeler evde sundukları hizmetleri, Büyükşehir Belediyesi Kanunu'nun yedinci maddesine ve Belediyeler Kanunu'nun 14. Maddesine dayandırarak gerçekleştirmektedirler. Türkiye'de evde bakım hizmetlerinin yürütülmesinden ve denetiminden sorumlu olan SB ve ASHB'ların görev paylaşımının gerekçesini hizmet sunulacak kitlenin ve sunulacak hizmetlerin içeriğinin farklı olmasına dayandırmaktadır. SB tarafindan hizmet sunulacak hedef kitle, hasta olarak (RG, 2005a; RG, 2005b; SB,2010) ASHB tarafından hizmet sunulacak temel kitle ise sağlıklı yaşlı ve bakıma muhtaç özürlü olarak tanımlanmıştır (RG, 2008). Hasta, sağlıklı yaşlı ve bakıma muhtaç kişilerin gereksinimlerinin birbirinden farklı ve birbirinden ayrı sunulması gerekliliği ön kabulü ile oluşturulan Türkiye evde bakım sistemi, hizmet sunumu sırasında kurumların ve hizmet sağlayıcıların çeşitlenmesi aynı konuda birçok hukuksal düzenlemelerin oluşmasına da sebep olmuştur.

Türkiye'deki evde bakım hizmetlerine ilişkin mevzuatın incelenmesi ve uygulamaların gözlemlenmesi sonucunda Sağlık Bakanlığı, Aile ve Sosyal Hizmetler Bakanlığı, yerel yönetimler, SB ve ASHB izin almadan kayıt dışı sunulan hizmetler hiçbir kurumdan destek almadan aileler tarafından sunulan geleneksel hizmetler ve aile tarafından finansmanı sağlanan göçmenler tarafından sunulan hizmetler olmak üzere temel olarak altı farklı evde bakım hizmeti modeli bulunmaktadır. Bunların bazıları daha etkin olarak kullanılırken, bazıları sadece mevzuat düzeyinde kalmış ve uygulamaya geçememiştir. Türkiye'de saptanan evde bakım uygulamalarının tümü aşağıda verilmiştir.

Türkiye'de Evde Bakım Hizmet Sunum Biçimleri

1. Sağlık Bakanlığı tarafından yürütülen evde bakım hizmetleri

- Aile hekimleri kapsamında sunulan hizmetler.

- Hastaneler bünyesinde oluşturulmuş evde sağlık birimleri tarafından yürütülen hizmetler.

- Ağız ve diş sağlı̆̆ı merkezleri tarafından yürütülen hizmetler.

- SB izni ile açılan özel evde bakım kuruluşları tarafından yürütülen hizmetler.

\section{Aile ve Sosyal Hizmetler Bakanlığı tarafından yürütülen evde bakım hizmetleri}

- ASHB izni ile açılan özel evde bakım kuruluşları tarafından yürütülen hizmetler.

- ASHB tarafından aile üyelerine sağlanan nakit yardımı kapsamındaki hizmetler. 
- ASHB izni ile açılan yatılı bakım kurumları tarafından yürütülen evde bakım hizmetleri.

- ASHB izni ile açllan gündüz bakım merkezleri tarafından yürütülen hizmetler

Yerel yönetimler tarafından sağlanan hizmetler.

4. SB ve ASHB izin almadan kayıt dışı sunulan hizmetler

5. Aile üyeleri tarafından verilen geleneksel bakım hizmetleri.

6. Göçmenler tarafından yürütülen hizmetler.

\section{Yöntem}

Araştırma, Almanya'da (Berlin Eyaleti) ve Türkiye'de evde bakım hizmeti sağlayan evde bakım kurumu yöneticilerinin, evde bakım hizmetleri konusundaki görüşlerini belirlemeye yönelik nitel araştırmadır. Evde bakım kavramının bileșenindeki kültürel dinamiklerin etkisini daha iyi yansıtabilmek için alanın uzmanları ile derinlemesine görüşmeye dayalı niteliksel araştırma tercih edilmiştir. Araştırmada görüşmeler araştırmacı tarafından geliştirilmiş yarı yapılandırılmış form aracılığı ile gerçekleştirilmiştir. Niteliksel çalışma kapsamında içerik analizi ve betimsel analiz yapılmıştır.

Almanya'daki evde bakım kuruluşları verdikleri hizmet içerikleri, hedef kitle ve organizasyon yapıları dikkate alınarak on farklı grup olarak ele alınmıştır. Olușturulan her farklı gruptan en az bir örnek kurum seçilmiştir. Türkiye'de ise evde bakım hizmetleri farklı kurumsal yapılara bağlı olarak sunulduğundan tüm farklı örgütlenme yapıları ve hizmet içeriklerini kapsayacak biçimde bir örneklem seçimi yapılmıştır. Örneklem seçiminde amaçlı örnekleme yöntemlerinden uygun örnekleme yöntemi tercih edilmiștir (Merriam, 2009/2013: 78). Araștırmada görüşmenin verimliliği artırmak amacıyla günde en fazla iki görüşme gerçekleștirilmiştir.

Bu araştırma için Akdeniz Üniversitesi Etik Kurulundan gerekli izinler alınmıştır. Çalışmaya katılanlarının tamamı araștırma ile ilgili olarak aydınlatılmış ve görüşmeyi kabul etmeleri onam olarak değerlendirilerek yazılı onam alınmamıștır.

\section{Araştırmanın Bulguları}

Araştırma grubuna ilişkin sosyo-demografik özellikler incelendiğinde 23 katılımcının onu Almanya'dan, onüçü Türkiye'dendir. Katılımcıların 12'si kadın ve 11'i erkektir. Grubun yaş ortalaması 44,65 olarak saptanmıștır. Almanya'dan katılan katılımcıların evde bakım hizmetlerinde çalıșma süresi ortalama 12 yıl iken Türkiye'deki katılımcıların 3,8 yıl olarak saptanmıştır. Tüm katılımcllar yüksek öğrenim mezunudur.

Gerçekleştirilen görüşme kayıtları (1-10 numaralı görüşmeciler Almanya, 11-23 numaralı görüşmeciler Türkiye) incelendiğinde, bağlantılı ifadeler kodlanarak her iki ülke için karşılaştırma yapmaya olanak sağlayabilecek tema ve alt tema başlıkları belirlenmiştir.

\subsection{Evde bakım hizmetleri ile ilgili tanımlar}

Evde bakım hizmetlerinin içeriğinin tanımlanmasında Almanya'daki görüşmeciler arasında büyük oranda uzlaşım bulunurken, Türkiye'deki görüşmeciler arasında uzlaşım olmadığı belirlenmiştir. Almanya'daki görüşmeciler evde bakım hizmetlerini daha çok bütüncül yaklaşım içinde tıbbi ve sosyal bakım hizmetlerini içerecek biçimde tanımlamaktadır; bu durum "Kişiye evinde sunulabilecek her türlü tedavi hizmetleri ile birlikte onun yaşamını devam ettirebilecek her türlü hizmetin sunulması" (G7-Özel Evde Bakım Kuruluşu) şeklindeki görüşmeci ifadesinde göze çarpmaktadır. Türkiye'de evde bakım hizmetlerinde farklı hizmet sunucuları ve farklı hizmet içerikleri olması nedeniyle hizmet içeriği bağlamında Almanya'dakine benzer uzlaşı söz konusu değildir. Türkiye'deki bir görüşmeci evde bakım hizmetini “Kendi evinde ona hastane şartlarını sağlamak" (G16 Evde bakım hizmeti veren özel çalışan hemşire) şeklinde tanımlarken bir diğer görüşmeci ise "Evde bakım sadece tıbbi ihtiyaçla sınırlı kalmaz.... Sadece hekimlik üzerinden evde bakım tanımı yapmak mümkün değildir." (Görüşmeci 10 Aile hekimi) ifadesini kullanmaktadır.

Evde bakım hizmetlerinde tıbbi ve sosyal hizmet ayırımı ve önceleme sorunu, $A B$ ülkelerinde de tartışılmaktadır (EC, 2011:17, Chen, 2012:31). İngiltere'de yapılan bir araştırmada konu ele alınmış ve tıbbi bakımının sosyal bakımdan daha yüksek öncelikli olarak değerlendirildiği saptanmıștır (Chen, 2012:31). 
Birçok ülkede, bakım hizmetlerinde, ana hizmet sağlayıcı 1970'li yıllara kadar aile olmasına karşın günümüzde bakım hizmetleri tüm dünyada devletin (1), ailenin (2) ve devlet ile ailenin birlikte (3) sorumlulukları paylaştğ̆ modeller olmak üzere temelde üç farklı biçimde ele alınmaktadır (Chen,2014). Devletin sorumluluklarını belirlemek, teorik olarak kolay olmasına karşın, pratikte bu sorumlulukların sınırını çizmek oldukça güçtür (Lorau, 2001:112). Ancak zamanla bu rolde değişim yaşanarak bakım hizmetleri, kamusal bir görev ve yükümlülük olarak değerlendirilmeye başlanmış ve aile ile gönüllü kuruluşların bakım hizmetlerindeki yükümlülügü azalmıştır (Morris ve Harris, 1972; Tønnessen vd., 2011; Campbell ve Morgan, 2005; Munchus vd.,1999; Santana, 2010).

\subsection{Evde bakım hizmetinin kapsamı}

Araştırma kapsamında görüşmecilere göre, evde bakım hizmetleriyle ilgili iki temel yaklaşım bulunmaktadır. Görüşmecilerin bazıları evde bakım hizmetlerinin sosyal devlet ve insan hakkı kavramı temelinde ele alınması gerektiğini belirtirken, bazı görüşmeciler ise evde bakımın bir çeşit "hayır işi" olarak ele alınması gerektiğini ifade etmişlerdir.

Türkiye'den katılan görüşmeciler, evde bakım hizmetinin hak boyutunu "sosyal devlet olmanın en önemli noktalarından birinin bu olduğunu düşünüyorum." (G12 Evde Sağlık Koordinasyon Merkezi Yöneticisi) ve "bakım gereksinimi olan bireylerin bu hizmete ulaşması bir lütuf değil, hak olarak ele alınmalıdır." (G15 Belediye Evde Bakım Birimi) biçiminde ifade etmişler ve evde bakım hizmeti alma hakkının kullanımında "devleti" birincil sorumlu olarak tanımlamışlardır. Evde bakım hizmetlerinin "hak" olarak görülmesi, kamusal bir yükümlülük getirmekte ve aile bireylerinin bakım hizmetlerinde birincil hizmet sağlayıcı ve sorumlu olarak değerlendirilmemesi gerektiğini ortaya çıkarmaktadır.

Türkiye'deki bazı görüşmeciler ise evde bakım hizmetini "hayır işi”" olarak değerlendirmektedir. Örneğin bir yönetici “... evde sağlık bir hayır işi. Bizim personelimiz evde sağlığı hayır işi olarak gördüğünden hastaya yaklaşımı da farklı oluyor. İșini severek yapıyor, o nedenle çok fazla sorun yaşanmıyor diye düşünüyorum" șeklinde ifade etmiștir.

Ancak Almanya'dan çalışmaya katılan, kâr amacı gütmeyen ve temelinde hayır ve yardımseverlik olgusu yatan Caritas, AWO ve Diakonie adlı üç kuruluşun evde bakım yöneticisi olan görüşmecilerde yaptıkları işi profesyonel bir iş olarak tanımlamaktadırlar. Almanya'daki görüşmecilerin birçoğu konuyu profesyonel bir hizmet olarak gördüklerini ifade etmişlerdir. Evde bakım hizmetlerinin hayır işi olarak görülmesinin, profesyonelleşmeden uzaklaşılmasına ve gönüllülük esaslı bir yönelim içerisinde olunmasına neden olabileceği düşünülmektedir. Thabethe (2011:790), evde bakım hizmetlerinin profesyonel bir iş olduğunu ve gönüllülük temelli yapılacak bir iş olmadığını belirtmektedir.

Evde bakım hizmetlerinin gelişim süreci incelendiğinde, evde bakım hizmetlerinde gönüllü çalışmacılar ve kâr amacı gütmeyen sivil toplum örgütleri önemli yer tutmuştur (Ryder, 1960:11351136; Schuster vd., 2013). Avrupa'da ve Amerika kıtasında birçok ülkede evde bakım uygulamaları öncelikle, sivil toplum kuruluşları (STK) tarafından başlatılmış, kamu ve özel sektör daha sonra sistem içine entegre edilmiştir (Schulmerich, 1999, Dwyer vd., 2014:12). Türkiye'de ise STK'lar bu süreçten farklı olarak evde bakım hizmetlerinde çok sınırlı yer almaktadır. Profesyonelliğin ön plana çıkmasına rağmen evde bakım hizmetlerinde aile üyelerinin önemi, hem Türkiye'deki hem de Almanya'daki görüşmeciler tarafından ifade edilmektedir. Evde bakım hizmetlerinde ailenin katılımcı olması, amaca ulaşmada kolaylaştırıcı rol üstlenirken hasta, hasta ailesi ve sağlık personeli arasındaki eşgüdümü de artırmaktadır (Çoban vd., 2005).

Avrupa Birliği ülkelerinde ölümlerin \%75'inden fazlası hastanelerde gerçekleşmektedir (WHO; 2011:9). Grande, Addington- Hall ve Todd'a (1998) göre; hastanede ve huzurevlerinde ölüm oranının yüksek olması, son dönem bakım hizmeti verebilecek kişilere sahip olmamaları ve ek bakım ihtiyacı duymaları ile açıklanmaktadır. Evde bakım hizmetlerinin hastane ve bakım merkezi hizmetlerine alternatif olarak değerlendirilmesi Almanya'daki ve Türkiye'deki görüşmeciler tarafından "Evde bakım hasta ve yaşlı, bakıma muhtaç insanların kendi evinde bu bakımdan faydalanmasıdır. Gidip yaşlı evlerinde kalmaktansa kendi evlerinde hizmet almalarıdır" (G1-Özel Evde Bakım Kuruluşu) ve "Evde bakım hastanın evde konforunu daha iyi sağlamak için yapılan bir sistem kendi evinde ona hastane şartlarını sağlamak hasta ve hasta yakını için en birinci önem taşıyan şey" (G16 Evde Bakım Hizmeti Veren Özel Çalışan Hemşire) şeklinde belirtilmiştir. 


\subsection{Evde bakım hizmetlerinin denetlenmesi}

Evde bakım hizmetlerinin sunumu sırasında personel nitelikleri daha fazla ön plana çıktığından ve personel denetlemenin daha güç olmasından hizmet kalitesinin personel odaklı değerlendirilmesinin dezavantaj olarak görüldüğü "evde bakımda personeli denetlemek çok zor". (G2-Özel Evde Bakım Kuruluşu) ve "kontrol etmek çok daha zor. İnanmak zorundasın. Personeline inanmak zorundasın. Personeline huzurevlerine göre, hastanelere göre daha bağımlısın. 0 iyiyse sende iyisin o kötü ise sende kötüsün" (G7-Özel Evde Bakım Kuruluşu Yöneticisi) şeklinde ortaya konmuştur. Literatürde evde bakım çalışanlarının uygulamada özerkliklerinin artmasının hizmetin denetimini zorlaştırdığı ve yöneticinin çalışana olan bağımlılığının artmasına sebep olduğu belirtilmektedir (Stacey, 2005).

\subsection{Evde bakım hizmetlerinin dezavantajı}

Evde bakım hizmetlerinin hasta değerlerini öncelemeyi zorlayan yapısı ve bunun sonucu olarak her bir hastanın değerlerine göre davranmanın personel için zorluk oluşturduğu, "her bir kişiye ayak uydurmak zorunda. Bu da bir dezavantaj" (G2-özel evde bakım kuruluşu) şeklinde ifade edilmektedir. Thabethe (2011:790), evde bakım hizmetleri sunumu sırasında hasta talepleri ve hasta değerlerini önceleme sorununun, entegrasyon, akışkanlık, aerodinamik, bilinç ve dayanışma öğelerinin tümleşik biçimde kullanılması ile çözüleceğini belirtmektedir.

Türkiye'de evde bakım hizmetleri sırasında bürokratik işlemler önemli bir sorun olarak belirtilmezken, Almanya'da bürokratik işlemlerin önemli bir iş yükünü oluşturduğu, bazen hizmetin kendisinden daha önemli hâle geldiği saptanmıştır. Bir özel evde bakım yöneticisi bu durumu, evde bakım kuruluşunda bürokratik işlemleri yapan personelin de önemli bir görev üstlendiğini "idari işleri iyi yapamazsanız diğer yaptığınız işler bir işe yaramıyor. Yazışmaları yapan personel, bakım işlerini yapan personel kadar önemli" (G7-Özel Evde Bakım Kuruluşu Yöneticisi) sözleriyle ifade etmiştir. Türkiye'deki görüşmecilerin birçoğunun kamu görevlisi olduğu göz önüne alındığında, bürokrasinin bir sorun olarak belirtilmemesinin gerçekten bürokratik işlemlerin azlı̆̆ından mı yoksa devleti eleştirmek endişesi ile mi olduğunu sorgulamak gerekmektedir.

\subsection{Evde bakım hizmetlerinin avantajı}

Almanya ve Türkiye'deki görüşmeciler tarafından evde bakım hizmetlerinin hasta özerkliğinin gerçekleștirilmesine olan katkısı avantaj olarak değerlendirilmektedir. "Kişi kendini özel hissediyor." (G18 TSM YöneticisiTürkiyede) ve "Bir de kişisel bir şey sonuçta kendisi karar veriyor" (G8-Kâr amacı gütmeyen evde bakım kuruluşu) ifadeleri söz konusu değerlendirmeyi göstermektedir. Literatürde evde bakım hizmetlerinin sadece hasta özerkliğinin gerçekleştirilmesine değil, aynı zamanda çalıșan özerkliğinin de gerçekleștirilmesine olanak sağladığı belirtilmektedir (Hodson, 2001; Wardell, 1992 'den akt. Stacey 2005).

\subsection{Bakım hizmetlerinde kadın}

Tarihsel süreç içinde bakım hizmetleri kadına yüklenmiş bir ödev olarak görülmektedir (Karapehlivan Şenel, 2012; Marx, 1997:381; Öz, 1998). Bakım piyasasında cinsiyete göre ayrımın sıradanlaştırılması, hastaların ve yaşlıların bakımı için de zaten doğal olarak yatkınlaştırılmış, kadınları öneren toplumsal bir normu karşımıza çıkarmaktadır (Abel ve Nelson, 1990 'dan akt. Stacey ve Ayers, 2012). Bu bağlamda Almanya'daki görüşmeci tarafından bakım hizmetlerinde temel görevin kadında olduğu tarihsel dinamikler çerçevesince şu şekilde ifade edilmiştir: "bu meslek tarihte de rahibelerden çıkmıştır. Yani kadınlardan çıkmıștır. Birisi hasta olduğu zaman anne bakar, baba bakmaz ya da kız kardeş bakar. Ya da gelin bakar, damat bakmaz. Sektörde erkek oranları çok az. Yani bu işi yapmak isteyenler az. Gerek işin kadın işi olarak görülmesi, gerekse bayanı her tarafa gönderebiliyorsunuz her iși yaptırabiliyorsunuz. Bulaşı̆̆ı yıkayabiliyor. Alışverişe gidebiliyor. Ama erkek yapamıyor. Genelde bu işi yapan erkek sayısı az. Ayrıca vücut bakımında erkeklerin yer alması sorun olur. Genelde bayanlar erkeklere göre daha fazla tercih ediliyor. Alman yaşlı bayanlarda erkek sorun olmuyor. Türkiyeli bir bayanın vücut bakımı için erkeği gönderemezsiniz. Kültürel yönden ve dinî yönden bir erkek kadına vücut bakımı yapamaz. Yabancı bir erkek yapamaz. Ama bir bayan erkeğe vücut bakımı yapabiliyor. Aşırı dinci de olsa onda bir sorun olmuyor. Bir erkeğin bir bayana vücut bakımı yapması sorun. Türkiyeli hastalarda toplumun ne düşündüğü çok önemli oluyor. Daha çok başkaları için yaşıyorlar. Davranışlarını başkalarına göre yönlendirebiliyorlar." (G2-Özel Evde Bakım Kuruluşu). Bakımın belli bir cinse yüklenmiş ödev oluşturması, bu hizmet alanında çalışan kadınların kendi aile birimlerinde de aynı ödev yükümlülüğü ile karşı karşıya kalmasına neden olmaktadır (Armstrong ve Armstrong; 2010; George, 2008; Malacrida, 2009). Bunun da çalışanlar 
için olumsuzluk yarattığı, Almanya'daki görüşmeciler tarafından, “... Personelin çoğu bayan, onların da kendi çocukları var. Vardiyalı çalışmada sorunlar yaşanabiliyor. İş ve çocuk aynı zamanda yürümesi zor olabiliyor. Bizim işimiz 365 gün 24 saat gerektiriyor. Dönem dönem hafta sonları çalışmaları gerekiyor. Dönem dönem öğleden sonra ya da gecenin geç saatlerinde çalıșmaları gerekebiliyor. Orada da çok ciddi sorunlar yaşayabiliyoruz personel açısından." (G2-Özel Evde Bakım Kuruluşu) şeklinde belirtilmiştir.

Hem Almanya'daki hem Türkiye'deki görüşmeciler evde bakım hizmetleri ile sağlık kurumları arasındaki entegrasyonun kurulamaması sorununu "Hastanelerle dialogda da sorun yaşanabiliyor. Mesela hasta hastaneye düştü, hastaneden eve döndüğünde tekrar hizmetin devam edebilmesi için koşulların hazırlanması gerekiyor." (G1-Özel Evde Bakım Kuruluşu) ve "Kurumlarla ortak bir çalışma ve veri tabanı oluşturulmadığı için mükerrer ziyaretler olabiliyor. Bu da iş gücü kaybına neden oluyor." (G15 Belediye Evde Bakım Birim Sorumlusu) sözleriyle ifade etmişlerdir. Literatürde Almanya'da hastaneler, yatılı bakım kuruluşları ve evde bakım kuruluşları arasında entegrasyon sorunu olduğunu vurgularken hastalıkların tedavisinden, bakımından ve kurumlar arası entegrasyon ve görev dağılımına kadar uzanan sistematik bir sorunlar silsilesine neden olduğunu belirtmektedir (Eenoo vd., 2014:33; Dini vd., 2012; Satzinger vd., 2005).

\subsection{Evde bakım hizmeti sunumundaki aileyle ilintili sorunlar}

Kişilerin, aile üyeleri tarafından verilen bakımı, evde bakım kuruluşları tarafından sunulan hizmete göre daha çok tercih ettikleri belirlenmiştir (Szebehely ve Trydegard, 2012: 305, 307). Stacey tarafından yapılan araştırmada da ailenin bakım hizmetlerinde yer alması gerektiği belirtilmiştir (Stacey, 2012: 53). Ancak bu istem beraberinde bazı riskleri de getirmektedir. Kişilerin evlerinde aile üyeleri tarafından bakılması sırasında, aile üyelerinde özellikle bakım hizmetinden sorumlu kișide bazı sağlık sorunlarına neden olabileceği Almanya'daki ve Türkiye'deki görüşmeciler tarafından "yani kendilerini genç yaşta annelerinden daha hasta duruma getiriyorlar ya da eşlerine bakarken daha çok hasta olmuşlar ve bunu görmüyorlar. Onlar benim gelecek hastalarım oluyorlar yani ilerideki" (G4-Özel Evde Bakım Kuruluşu) ve "aileler bakıma ihtiyacı olan kişilerle yaşadıklarında onlardan hasta olmayı öğreniyorlar, burada sosyal bulaşma olduğunu düşünüyorum." (G15 Belediye Evde Bakım Birim Sorumlusu) şeklinde belirtilmiştir. Arai ve diğerlerinin (2014: 85) çalışmasında da benzer bulgulara rastlanılmış, aile üyeleri tarafından evlerinde bakılan hastaların yakınlarında depresyon görülme sıklığında artış olduğu saptanmıştır. Aile içinde yaşanabilecek olumsuzlukların bireylere olan etkisi edebiyatta da yer almış ve Fransız yazar Marcel Proust'un "Sainte-Beuve'e Karșı" adlı eserinde söz konusu etki ve yaşlı ile yaşamanın güçlüğü Victor Hugo'nun "Yaşlılık gözlerde başlar bana kalırsa/ Daha çabuk yaşlanır insan hep yaşlılara bakarsa" dizeleriyle belirtilmiștir (Proust, 2006: 82). Ancak hizmet verenlerin sağllk riskleri olmasına rağmen sigorta kuruluşları ve hükümetler maliyetleri azalttığı gerekçesi ile evde informal bakımı özendirmekte ve devlet politikası haline getirmektedirler (Arntz ve Thomsen, 2011; Costa-Font ve Patxot, 2004; Golberstein vd., 2009; Meng, 2013; Simonazzi, 2009; Yong ve Saito, 2012, Resmî Gazete [RG], 1963). Kişilerin istemlerinin de informal bakım yönelimli olması devletlerin informal bakımı maliyet düşürücü araç olarak görme politikasıyla örtüşerek güçlendirmektedir.

\subsection{Evde bakım hizmeti sunumundaki personelle ilintili sorunlar}

Türkiye'deki görüşmeciler evde bakım hizmetlerinde profesyonel çalışanlarda tükenmişlik ve isteksizlik ile ilgili bir görüş bildirmemelerine karşın Almanya'daki görüşmeciler tükenmişliğin önemli bir sorun olduğunu belirtmiş̧lerdir. Bir görüşmeci bu durumu "bütün gün bu işi yaptığımız için bir gün stop diyoruz. Bu çok da insani bir durum aslında. Çünkü onlar ile sürekli beraber olmak yoruyor tabii." şeklinde ifade etmiştir. Literatürde evde bakım personelindeki aşırı iş yükünün ve stresin depresyona (Barnes vd., 1992'den akt. Naruse vd., 2011) ve yaşl suiistimaline ve ihmaline sebep olduğu (Nikura vd., 2009; Schiamberg ve Gans 2000'den akt. Naruse vd., 2011) ve carpal tunel sendromu geliştirdiği (England ve Dyck, 2012: 1081) belirtilmektedir.

Evde bakım sektöründe personel devir oranı yıllık \%50-75 gibi yüksek oranlarda gerçekleşmektedir (Institute of Medicine, 2008; U.S. General Accounting Office, 2001). Literatüre paralel hem Almanya'daki hem de Türkiye'deki görüşmeciler personel devir oranının yüksek olduğunu belirtmişlerdir. Almanya'daki bir görüşmeci bu olguyu "Bu alanda bir kişiyle uzun süre çalışamıyorsun. Ortalama bir kişinin bir iş yerinde çalışma süresi bir yıl diyebiliriz." (G3-Özel Dal Evde Bakım Kuruluşu) sözleriyle ifade etmiştir. Yüksek personel devir oranlarının yaratabileceği olumsuzluklar ise "personelin, kaliteli ve uzun vadeli eleman olması çok önemli". (G2- Özel Evde 
Bakım Kuruluşu), "bizim insanlar aynı yüzü ister. Çoğu zaman sağlayamıyorlar bunu" (G5-Sigorta Kuruluşu) ve "diyor ki ben bir kişiyi bileyim benim evime bir kişi gelsin. Aslında güven unsuru var. Yani evinize yabancı birilerinin girip çıkmasını çok istemiyor insanlar. Özellikle de yaşlılar alıştığı kişiyle sürekli devam etmek istiyor. Ama bu bizde çok mümkün olmuyor." (G13 Özel Evde Bakım Kuruluşu) sözleriyle belirtilmektedir. Literatürde de evde bakım hizmetlerinde uzun süre aynı kişiden hizmet alamama güçlügü sektörün zayıflıkları arasında değerlendirilmektedir (England ve Dyck, 2012:1081). Zeytinoğlu ve diğerleri de (2009) evde bakım hizmetlerinde, hizmet alanların aynı evde bakım çalışanı tarafından verilen bakımın devamlılığını beklemelerinin olağan olduğunu belirtirken söz konusu devamlılığın sağlanmasının rekabete dayanan piyasa modellemesi içerisinde yer alan evde bakım sisteminde neredeyse olanaksız olduğunu ifade etmektedirler. Türkiye'de gerçekleştirilen görüşmelerde hizmet alanların ve ailelerin evde bakım hizmeti sunumunda personel değişiminin sık olmaması beklentilerinin kurumlarca karşılanmasında sorun olduğu, çözüm olarak da ailelerin göçmen bakım personeline yöneldikleri saptanmıştır. Özel evde bakım yöneticisi bu durumu "Bir hizmet sunduğumuz için belli saatler içinde çalışanımızı yönlendirebileceğimiz için artık biz bir hizmet için minimum üç tane çalışanımızı o eve sokmak zorundayız. Yani bir gün biri, diğer gün başka biri nöbetçi sistemi şart. Aileler bazen buna sıcak bakmıyor. Diyor ki ben bir kişiyi bileyim, benim evime bir kişi gelsin. Aslında güven unsuru var. Yani evinize yabancı birilerinin girip çıkmasını çok istemiyor insanlar. Özellikle de yaşlılar alıştığı kişiyle sürekli devam etmek istiyor. Ama bu bizde çok mümkün olmuyor. Kendileri bulduğunda, yabancı uyruklu bir bayan bulduğunda tabii o riskleri de göz alarak sağlık risklerini kabul etmiş oluyorlar" (G13 Özel Evde Bakım Kuruluşu) biçiminde ifade ederken "bakım hizmetindeki güven" değerinin korunmasının gerekliliğine vurgu yapmaktadır.

Türkiye'de yabancı uyrukluların sıklıkla sektörde yer aldığı, hatta izinsiz olarak çalıștıkları ve bunun da sorunlar oluşturduğu, görüşmeciler tarafından ifade edilmiştir. Türkiye'de evde bakım hizmetlerinde, yurt dışından gelen ve izinsiz çalışan personelin hasta güvenliğini riske attığı; "evde kaçak çalışanlar ciddi sıkıntı yaratıyor. Birçok hastamızda biz şunu gördük, yurtdışından gelen hekim hasta bakıcılı̆̆ı yapıyor. Bir hekimin vereceği destek daha iyi bile olabilir, ama hastaya bir şey gelse başına hiçbir şey kanıtlayamıyor." (G13 Özel Evde Bakım Kuruluşu Yöneticisi) şeklinde belirtilmektedir. Almanya'daki görüşmeciler tarafından, evde bakım hizmetleri sunumunda yasadışı çalışma ve göçmen çalıştırmadan kaynaklanan sorunlar ifade edilmemektedir. Döhner vd.ne (2008) göre; Almanya'da göçmen yaşlı bakım personeli sorunu kamu ve politika yapıcılar tarafından son birkaç yılda fark edilmeye başlanmıştır.

Yapılan çalışmalar evde bakım çalışanlarının gelirlerinin tatmin edici düzeyde olmadığını, huzurevi ve hastane çalışanlarına göre daha düşük olduğunu göstermektedir (Hillier ve Barrow, 2007:313; Twigg, 2000; Delp, 2006:21). Çalışmada da evde bakım hizmetlerinde çalışmak isteyen personel bulma ile zorluğunun nedenlerinden birisinin elde edilen ücret olduğu "...Çok kazanmıyorlar yani. 0 yüzden gelirlerin biraz yükseltilmesi gerekiyor. Mesleğe çekmek için. Asıl sorunlardan biri.” (G1-Özel Evde Bakım Kuruluşu) sözleriyle ifade edilmektedir.

Hizmet alan kişilerin memnuniyetinin ve nitelikli bakım hizmetinin sağlanması için çalışanların niceliksel ve niteliksel yeterliliklerinin önemi genel kabul görecektir. Ancak Almanya'daki görüşmeciler hizmet verenlerin niteliksel eksikliğini "Ev hanımları, hiç bakımla alakası olmayan insanlara üç dört günde öğretiliyor, insanların üzerlerine bırakılıyor bu da çok büyük bir sorun" (G5Sigorta Kuruluşu) vurgularken, Türkiye'deki görüşmeciler ise “...personel ile asıl sorun sayısal anlamda yetersizlik. Bilgi düzeyinde bir sorun yok, hepsi sağlıkçı, sonuçta verilen hizmet belli, o verilen hizmeti de karşılayamayacak niteliksiz personel olduğunu düşünmüyorum." (G17 Halk Sağlı̆̆ Kurumu) sözleriyle temel sorunun niteliksel değil niceliksel olduğunu belirtmektedir. Bu yaklaşımın temelinde Türkiye'de evde bakım hizmetlerinin daha çok medikal bir boyut olarak algılanması ve ev ve hastane bakımı arasında mesleki beceri bağlamında ciddi farklılık görülmemesinden kaynaklandığı düşünülmektedir.

Türkiye'deki görüşmeciler evde bakım hizmetlerindeki personel istihdamında, sınırlı kaynakların akılcı kullanımı bağlamında dikkatli olunması gerektiğini özellikle ifade etmektedir. Personel odaklı sınırlı kaynakların kullanımı kapsamında farklı meslek gruplarının oluşturulması gerekliliği ve bunun önemi "Her hizmet her bakım için hemşire lüks kaçabiliyor. Ki bu kadar hemşire ihtiyacının olduğu bir ülkede hemşire bulma sıkıntısını da düşünürsek çok doğru değil aslında. Son dönemde yaşlı bakım teknikeri bölümlerinin açılması çok büyük bir avantaj sağladı." (G13 Özel Evde Bakım Kuruluşu Yöneticisi) sözleriyle belirtilmektedir. Fransa'da da evde bakım sektöründe sınırlı 
kaynakların aktif kullanımı adına üst düzey beceri gerektiren bakım hizmetleri dıșında, eğitimli ve yaşlı bakımına özel bakım personellerinin kullanılması, bir politika olarak belirlenmiştir (DoniolShawa ve Lada, 2011).

\subsection{Evde bakım hizmeti sunumunda hizmeti alanla ilgili sorunlar}

Her iki ülkedeki görüşmeciler hizmet alanlar ve hizmet verenler arasındaki rol kargaşasına vurgu yapmışlardır. Görüşmeciler hizmet alanların, hizmet verenleri profesyonel bakım personeli olarak değil hizmetçi gibi gördüklerini "eve bulaşıkçı kız temizlikçi kız gelmiş diyorlar. Hastanın banyosunu ben yaptırayım sen evin genel temizliği yap, ütüsünü yap diyenler oluyor." (G7-Özel Evde Bakım Kuruluşu) ve "Hasta daha farklı hizmet bekliyor, personel verebileceği hizmeti veriyor; bu sefer hasta yakınlarıyla sıkıntı yaşıyor" (G17 Halk Sağlığı Kurum Yöneticisi/ Türkiye) ifadeleriyle belirtmişlerdir. Ayrıca Almanya'daki görüşmecilerden bir tanesi, hizmet alanların kendi kültürüne yakın sağlık personelinden beklentilerinin daha yüksek ve görev tanımları dışındaki işlemleri isteme yönelimli olunduğunu; "Türkiyeli hemşire ya da hemşire yardımcısına davrandıkları gibi Alman hemşirelere davranmıyorlar. Kendilerinden olan hemşireden, bakım personelinden daha çok şey istiyorlar, bakım planı dışında şeylerde istiyorlar." (G2 Özel Evde Bakım Kuruluşu Yöneticisi) sözleriyle ortaya koymuştur. Stacey'in çalışmasında da, hizmet alanların taleplerinin ve beklentilerinin çalışanların görev tanımları dışında olduğuna ilişkin bulgular saptanmıştır (Stacey, 2005:844). Yapılan bu araştırmanın bulgularına benzer biçimde, evde bakım hizmetlerinde, hizmet alanların özellikle bakım personelini etiketleme biçiminde "hizmetçi" olarak gördüklerinin belirtildiği başka çalışmalar da mevcuttur (England ve Dyck, 2012:1081; Hrzenjak, 2012).

\subsection{Evde bakım hizmeti sunumundaki finansman ile ilgili sorunlar}

Gereksinim duyan her bir birey için evde bakım hizmetlerinin eşit, nitelikli şekilde ulaşılabilirliğinin sağlanması için hizmetin finansman modelinin belirlenmesi önemlidir. Almanya'da evde bakım hizmetlerinin finansmanı görüşmeci tarafından "bir, bakım ve hastalık sigortası üzerinden, iki, belediye, üç özel sigortalar. Çok nadir durumlarda mesleki örgütler var ve bir insan meslek dolayısıyla hasta oldu ise mesleki örgütler o zaman destek oluyor. Bağlı olduğu örgüt üzerinden, kuruluş üzerinden de bu imkânlardan yararlanma olanağı var. Bakım sigortası var ama kısmi, hepsini kapsamıyor" (G1-Özel Evde Bakım Kuruluşu) şeklinde özetlenmiştir. Ancak evde bakım hizmetleri sırasında ödemelerin bazılarının zorunlu uzun dönem sigortasından, bazılarının sağlık sigortasından, bazılarının belediyelerin kaynaklarından, bazılarının cepten ve özel sigortadan karşılanması önemli sorun olarak değerlendirilmektedir (Klein-Lange 1998, Rosenbrock 1998, 'den akt. Satzinger vd., 2005). Konuyla ilgili olarak DSÖ direktörü Bear De "Almanya'da ve diğer ülkelerde bu sistemle ilgili hâlâ birçok sorun bulunduğunu, özellikle sürdürülebilirlilik, bakımın dağıtılması ve olası maliyetlerden ailelerin korunumu ile ilgili problemlerin hâlâ mevcut olduğunu, hızlı yaşlanan bir nüfus dikkate alındığında uzun dönem bakım için doğru bir modelin bulunmasının aciliyetinin arttığını" belirtmektedir (WHO,2012).

\subsection{Evde bakım hizmeti sunumunda rekabetin neden olduğu sorunlar}

Evde bakım sektöründe çok yoğun rekabet yaşanmakta ve yaşanan rekabet sürecinde yasal ve etik olmayan, dolayısıyla haksız rekabete yol açan durumlar gelişmektedir. Çalışmada da evde bakım hizmetlerinde kurumlar arasındaki rekabet çeşitli biçimlerde sorun olarak hem Almanya'daki hem de Türkiye'deki görüşmeciler tarafından belirtilmiştir. Türkiye'de görüşmeciler, haksız rekabetin özel kuruluşlar arasında personel rejimine uyulmamasından ve yasalara uygun personel çalıştırılmamasından kaynaklandığını, yasalara uygun personel çalıştıranların ise maliyetlerinin artması nedeniyle mağdur olduklarını; "bazı kuruluşlar maalesef part-time adı altında tanımadıkları bilmedikleri hemşireleri hastalara yönlendirerek, hizmet kalitesinin düşürülmesine sebebiyet veriyorlar. Belki hemşire olduğu bile bilinmeyen, çünkü diplomasını sorgulamıyorlar, belki de hemşire olmayan birini hemşirelik hizmetine yönlendirebiliyorlar. Bunlar haksız rekabete sebep oluyor Sonuçta full-time çalışanın bize getirdiği maddi yükle part-time çalışanın getireceği yük çok farklı" (G13 Özel Evde Bakım Kuruluşu Yöneticisi) şeklinde ifade etmektedir. Almanya'da ise, rekabetin daha çok bu kuruluşlar arasında etik ve hukuki olmayan yöntemlerle "müşteri" çekme anlamında yaşandığı; müşterilere ve yakınlarına çeşitli hediyelerden, altın ve para vermeye uzanan bir teşvik yöntemi kullanıldığı şeklinde belirtilmiş ve bu haksız rekabet yaklaşımlarının önemli bir sorun olduğu, birçok görüşmeci tarafından belirtmiştir. Örneğin: "Evde bakım kuruluşları arasında çok çirkin bir rekabet var. Hasta kapma yarışına girdiler. Bu yarış kontrolsüz bir şekilde sürüyor. Evde bakım kuruluşları sağlık sektörü içerinde kötü bir imaja sahip olmaya başladılar. Kendi 
kendilerini kirletiyorlar" (G3-Özel Dal Evde Bakım Kuruluşu Yöneticisi). Türkiye'deki görüşmeciler tarafından hasta tercihlerini etkilemek için uygulanan etik ve yasal olmayan promosyonel yöntemlere ilişkin bir durum belirtilmemiştir. Bu durum Türkiye'de evde bakım alanında özel sektörün etkisinin düşük olması ve şu an için bir rekabet olgusu ile karşılaşılmaması ile açıklanabilir. Ancak Türkiye'de evde bakım hizmetlerinin açık bir pazar haline gelmesi ile birlikte yașanabilecek olası riskler göz ardı edilmemelidir.

Almanya'daki görüşmelerde part-time çalışma ve izinsiz çalışma ile ilgili herhangi bir ifade yer almazken, Türkiye'de kâr amacı güden evde bakım kuruluşları tarafından önemli bir sorun, hatta haksız rekabetin önemli dayanaklarından biri olarak belirtilmektedir: "Üç-beş hemşire biraraya gelip evde bakım hizmeti vermemeli, takip edilmeli. ... hastanesi isim veriyorum ama birçok hastane için geçerli. Orda çalışan yoğun bakımdaki iki üç hemşire bir araya gelip bir hastaya evde destek verebiliyorlar. Bunun tamamen ortadan kaldırılması gerekiyor. ... Bunlara engel olunması gerekiyor ya da engel olunması istenmiyorsa maddi anlamda desteklenmesi isteniyorsa da kayıt altına alınarak part time çalışmalarına izin vererek bu sistemin uygulanması gerekiyor. Tam gün yasası sadece hekimlere değil hemşirelere de uygulanmalı." (G13- Özel Evde Bakım Kuruluşu). AB ülkelerinde, evde bakım sektöründe part-time çalışma biçimi, bir çalışma yöntemi olarak etkin bir biçimde kullanılmaktadır ve ülkeler yasal düzenlemelerini de oluşturmuşlardır (Genet vd., 2012:86). Almanya'da da part- time çalışma biçimi yasalar tarafından tanımlanmış ve evde bakım sektöründe önemli oranda part- time çalışan personel bulunmaktadır (Rothgang ve Igl, 2007: 61).

\subsection{Evde bakım hizmeti sunumunda güvenlikle ilintili sorunlar}

Almanya'daki görüşmeciler, evde hizmet sunumu sırasında karşılaştıkları sorunlar arasında çalışanlara yönelik şiddetten söz etmemiş̧lerdir. Oysa Türkiye'de evde bakım çalışanları, Türkiye'de her geçen gün sağlık çalışanlarına yönelik artan şiddetin bir yansımasının evde bakım hizmetlerinde de yaşanabileceğini “...oraya hizmet vermeye giden personel sonra sıkıntı yaşayıp ya da kötü muameleye maruz kalıp geri dönebiliyor. Ama Türkiye koşullarında yani her yerde bu sorun var bu sağlık personelinin hasta yakınlarıyla her zaman yașadığı sıkıntılardan bir tanesi hastanede bile oluyor." (G17 Halk Sağlığı Kurumu Yöneticisi) sözleriyle belirtmektedir. Almanya'da görüşmeciler, evde bakım hizmetlerinde çalışanlara yönelik şiddeti bir sorun olarak tanımlamasalar da Almanya'daki literatürde evde bakım çalışanlarına yönelik şiddetten söz edilmektedir (Büssing ve Hoge, 2004).

\section{$4 \quad$ Sonuç ve Öneriler}

Bu çalışmada evde bakım hizmetini tüm toplumu kapsayacak biçimde yaygınlaştıran ve büyük oranda zorunlu sigorta sistemi ile finanse eden Almanya'daki evde bakım kurumu yöneticilerinin görüşleri ile evde bakım hizmeti gereksinimi hızla artmasına rağmen henüz standart hizmet modeli oluşturamamış ülke olan Türkiye'deki evde bakım yöneticilerinin görüşleri karşılaştırılmıștır. Her iki ülkenin sistemi, evde bakım hizmetlerinin kuruluş gerekçesi, tanımı, kapsamı, finansmanı, personel çeşitliği, denetimi, var olan sağlık sistemi ile bağlantısı gibi temalar bağlamında karşılıklı olarak incelenmiştir.

Farklı gelişmişlik düzeyinde ve farklı kültürlere sahip olan iki ülkenin sistemsel, yaklaşımsal farklılıklar da gösteren evde bakım uygulamaları bütün olarak değerlendirildiğinde "evde bakım" kavramının sağlık kavramını ve sağlığın sosyal belirleyenlerini göz önüne almadan tanımlanamayacağı, toplumsal ve sosyal bağlamları olan sağlı hakkıyla doğrudan ilişkili olduğu ortaya çıkmaktadır. Tüm bunlar dikkate alındığında ise kavramın "bireyin yaşam niteliğinin artırılmasına yönelik sürdürülecek bakım hizmetlerinin bütüncül yaklaşım içinde, hizmet için özelleşmiş kurumsal mekanlar dışında bireyin yaşam mekânında sunulmasıdır" şeklinde tanımlanmasının uygun olduğu düşünülmüştür. Türkiye açısından söz konusu kavramsal yaklaşıma uygun örgütlenme için evde bakım hizmetlerine yönelik yeni bir model önerisi oluşturulması önemini korumaktadır. 
Hakem Değerlendirmesi: Dış bağımsız.

Çıkar Çatışması: Yazarlar çıkar çatışması bildirmemiştir.

Finansal Destek: Yazarlar bu çalışma için finansal destek almadığını beyan etmiştir.

Peer-review: Externally peer-reviewed.

Conflict of Interest: The authors declare no potential conflicts of interest with respect to the research, authorship, and/or publication of this article.

Grant Support: The authors received no financial support for the research, authorship, and/or publication of this article.

\section{Kaynakça/ References}

Abel, E, ve Nelson, M.K. 1990. Circles of care: Work and identity in women's lives. Albany: State University of New York Press.

Aile ve Sosyal Politikalar Bakanlığı (ASPB). (2013). Bakım hizmeti uygulama rehberi. Ankara: Aile ve Sosyal Politikalar Bakanlığı Aile ve Sosyal Politikalar Bakanlığı,

Arai, Y., Kumamotoa, K., Mizunoa, Y., ve Washio, M. (2014). Depression among family caregivers of community dwelling older people who used services under the long term care insurance program: A large-scale population-based study in Japan. Aging \& Mental Health, 18(1), 81

Arita, K., ve Ryu, H. (2013). A comparison of trends in research into home care services in Japan and Korea. Bio Med Central (BMC) Nursing, 12(18), 1-6.-91.

Armstrong, P. ve Armstrong, H., (2010). İşyerindeki kavga: Kanada sağlık hizmetlerindeki egemelik mücadelesi., Z. H.Akman (Ed.), Kapitalizmde sağlı sağlıksızlık semptomları içinde, (ss.163-187.). İstanbul. Yordam Kitap.

Arntz, M. ve Thomsen, S. L. (2011). Reforming home care provision in Germany -Evidence from social experiment. Zentrum für Europalische Wirtschaftsforschung $\mathrm{GmbH}$, 08-114.

Barnes, C. L., Given, B. A. ve Given, C. W. (1992). Caregivers of elderly relatives; Spouses and adult children. Health and Social Work, 17, 282-289.

Bentur, N. (2001). Hospital at home: What is its place in the health system. Health Policy, 55(1), 7179.

Büssing, A. ve Höge, T. (2004). Aggression and violence against home care workers. Journal of Occupational Health Psychology, 9(3), 206-219.

Campbell, L.A. ve Morgan, K.J. (2005) Federalism and the politics of old-age care in Germany and the United States. Comparative Political Studies, 38(8), 887-914.

Chen, H. L. (2012). Everyday experience of front-line professionals and in/formal carers: Long term care of older people in England, the Netherlands and Taiwan. International Journal of Public and Private Healthcare Management and Economics, 2(3), 27-39.

Chen, L.H (2014) Meeting the care needs of older people: Long- term care practice in England, the Netherlands, and Taiwan. In M. M. Mervio (Ed.), Contemporary social issues in East Asian societies: Examining the spectrum of public and private spheres, USA: IGI Global Hershey.

Costa-Font, J. ve Patxot, C. (2004). The intergenerational impact of long-term care financing alternatives in Spain. The Geneva Papers on Risk and Insurance, 29(4), 599-605.

Çoban, M., Şanlığlu, Bilgici, S., Oğuz, Y. (2005) Türkiye'de evde bakım hizmetleri ve olası etik sorunlar. Sağlık ve Hastane Yönetimi 2. Ulusal Kongresi Bildiri Kitabı, Ankara: Ankara Üniversitesi Sağllk Eğgittm Fakültesi Sağllk Yönetimi, 292-295. 
Dwyer, L. L., Harris-Kojetin, L. D., \& Valverde, R. H. (2014). Differences in adult day services center participant characteristics by center ownership: United States, 2012 (No. 164). US Department of Health and Human Services, Centers for Disease Control and Prevention, National Center for Health Statistics.

Doniol-Shaw, G. ve Lada, E. (2011). Work schedules of home care workers for the elderly in France: Fragmented work, deteriorating quality of care, detrimental health impact. Work, 40, 31-46.

Davis, R.E. (1994). Total quality management for home care. Maryland: Aspen Publication.

Delp, L. (2006). Job stressors among home care workers in California's consumer-directed model of care: The impact of job satisfaction and health outcomes, Yayımlanmamış Doktora Tezi, University Of California Public Health Department, California.

DePalma, J. A. (2008). Evidence needed to support home care in the future. Home Health Care Management Practice, 20(2), 186-188.

Dışişleri Bakanlığı. (2014) Türkiye-Almanya Federal Cumhuriyeti Siyasi İlişkileri. Web: http://www.mfa.gov.tr/turkiye-almanya_-siyasi-iliskileri.tr.mfa adresinden 10.11.2014 tarihinde erişildi.

Dini, L., Sarganas, G., Heintze, C. ve Braun, V. (2012). Home visit delegation in primary care acceptability to general practitioners in the state of Mecklenburg-Western Pomerania, Germany. Deutsches Arzteblatt International, 109(46), 795-801.

Dozeman, E., Schaik Digna, J. F., Van Marwijk Harm, W. J., van Stek Max, L., Beekman Aartjan, T. F. ve Horst Henriette E. (2011). Feasibility and effectiveness of activity-scheduling as a guided self-help intervention for the prevention of depression and anxiety in residents in homes for the elderly: a pragmatic randomized controlled trial. International Psychogeriatrics, 23 (6), 969-978.

Döhner, H., Lüdecke, D. ve Eickhoff, V. (2008). Migrant workers in home care for older people in Germany: The use and problems of legal and irregular care. Gerobilim, 1 (8), 2-13.

Eenoo, V., Declercq, L., Roest, A., Hein and on behalf of the IBenC consortium (2014). Review on the structure of community care of the six articipating countries and their benchmarking practices, IBenC consortium. S:33.

England, K. ve Dyck, I. (2012) Migrant workers in home Care: Routes, responsibilities, and respect: Annals of the Association of American Geographers, 102(5), 1076-1083.

European Commission (EC). (2011). Long-term care in the European Union. Brussel: EC, Employment, Social Affairs and Equal Opportunities DG Social Protection and Integration, Social Protection, Social Services.

European Union (EU) (2008). Long term care in the European Union. Luxemburg: European Commission, Luxembourg: Office for Official Publications of The European Communities.

European Union (EU) (2011). Directive 2011/24/EU of the European Parliament and of the Council of 9 March 2011 on the application of patients' rights in cross-border healthcare. Brussels: European Commission, Official Journal of the European Union.

Federal Statistical Office of Germany (2013). Statistical Yearbook, Germany Extract/ Chapter 2, Population, families, living arrangements 2012. Wiesbaden: Federal Statistical Office.

Genet, N., Boerma, W., Kroneman, M., Hutchinson, A. ve Saltman, R. B. (2012). Home care across Europe, current structure and future challenges. Denmark: World Health Organization (acting as the host organization for, and secretariat of, the European Observatory on Health Systems and Policies), $9,83$.

Genet, N., Kroneman, M. Ve Boerma W.G.W. (2013). Explaining governmental involvement in home care across Europe: An international comparative study. Health Policy, 110, 84- 93

George, A. (2008). Nurses, community health workers, and home carers: Gendered human resources compensanting for skewed health systems. Global Public Health, 3(1), 75-89. 
Glodny, S., Yilmaz-Aslan Y. ve Razum, O. (2011). Storytelling: an intervention to improve home care of Turkish migrants. Zeitschrift Für Gerontologie und Geriatrie, 44 (1), 19-26.

Golberstein, E., Grabowski, D.G., Langa, M.K ve Chernew M.E. (2009). Effect of medicare home health care payment on informal care. Inquiry, 46(1), 58-71.

Grande, G.E., Addington- Hall, J.M., ve Todd, J. (1998). Place of death and access to home care services: Are certain patient groups at a disadvantage? Social Science Medicine, 47(5), 565-579.

Gupta, N. (2013). Models of social and health care for elderly in Norway. Indian Journal of Gerontology, 27(4), 574-587.

Harris-Kojetin L, Sengupta M, Park-Lee E, Valverde R (2013) Long-term care services in the United States: 2013 overview. National health care statistics reports; No 1. Hyattsville, MD: National Center for Health Statistics. 2,8.

Heinicke, K. ve Thomsen, L. S. (2010). The social long term care insurance in Germany: origin, situation, threats and perpectives, Discussion Paper, 10-012. Bonn: Center of Economic Research (ZEW), .2,4,5,13.

Hillier, S.M. ve Barrow, M.G. (2007). Aging, the individual and society (Eighth Edition). USA: Thomson and Wadsworth, 313.

Hodson, R. (2001). Dignity at Work. Cambridge: Cambridge University Press.

Hrzenjak, M. (2012). Hierarchization and segmentation of informal care markets in Slovenia. Social Politics, 19(1). 38-57.

Institute of Medicine. (2008). Retooling for an aging America: Building the health care workforce. Washington: National Academy Press.

Jones, S. (2014). Home care ve PPACA: New challenges for a rapidly growing health care industry. Journal of Health Care Compliance, July - August, 35-61.

Karapehlivan Şenel, F. (2012). Tarihsel ve toplumsal süreçte kadın. Toplum ve Hekim, 27 (4), 246255.

Kersktra, A. ve Hutten, J. B. F. (1996). Organization and financing of home nursing in the Europen Union. Journal of Advanced Nursing, 24, 1023-1032.

Klein-Lange, M. (1998). Krankenversorgung. F. W. Schwartz (Ed.), Das public health buch içnde. Germany: Urban \& Schwarzenberg, 213-244.

Lange, J.W., Mager, D.R., ve Andrews, N. (2013) The ELDER expansion project: building cultural competence among long term home care workers. Applied Nursing Research 26, 58-62.

Littauer, D. (1960), Health services at home. The nature of health services. Public Health Reports (1896-1970) , 75(12), 1113-1115.

Livindhome (Reforms in Organisation and Governance of European care for older people and People with Disabilities) (2011) Executive Summary, Editors:Tine Rostgaard, Caroline Glendinning, Cristiano Gori, Teppo Gröger, August Österle, Marta Szebehely, Hildegard Theobald, Virpi Timonen, Mia Vabø; Living Indepedently at Home, Copenhagen, Teh Danish National Centre for Social Research.

Lorau, R. (2001). Bilinçaltında Devlet, (Çeviren: Işık Ergüden), Eserin Orijinal Adı:L'Etat-inconscient, İstanbul: Ayrıntı Yayınları.

Lottmann, R., Lowenstein, A. ve Katz, R. (2013). A German-Israeli Comparison of Informal and Formal Service Use Among Aged 75+. Journal of Cross-Cultural Gerontology, 28(29), 121-136.

Malacrida, C. (2009). Gendered ironies in home care: Surveillance, gender struggles and infantilisation. International Journal of Inclusive Education, 13(7),741-752.

Marx, K. (1997) Kapital, Birinci Cilt, (Çev: A.Bilgici), Beşinci Baskı, Ankara: Sol Yayınları. 
Meng, A. (2013). Informal home care and labor-force participation of household members. Empirical Economics. 44, 959-979.

Merriam, S. B. (2013). Nitel araştırma: Desen ve uygulama için bir rehber. (Edt:S. Turan, Çev:S. Turan ve D. Yılmaz). Ankara: Nobel Yayınevi.

Morris, R. ve Haris, E.A.B. (1972). Home health services in Massachusetts, 1971: Their role in care of the long-term sick. American Journal of Public Health (AJPH), 62 (8), 1088-1093.

Munchus,G, Roberts, V., Rivers, P.A., ve Gingerich, B.S. (1999) The US home health care industry: past, present, and future, Home Health Care Management Practice, 11(21), 21-30.

Nadash, P., Doty, P., Mahoney, K.J. ve M.V. Schwanenflugel (2012). European Long-Term Care Programs: Lessons for Community Living Assistance Services and Supports?. Health Services Research 47(1), 309-328.

Naruse, T., Nagata, S., Taguchi, A. ve Murashima, S. (2011). Classification tree model identifies homebased service needs of Japanese long-term care insurance consumers. Public Health Nursing, 28 (3), 223-232.

Nikura, M., Araki, H. ve Kishitani, Y. (2009). Kazoku kaigosha no youkaigo koureisha ni taisuru shintaiteki oyobi shinriteki gyakutai no sep- pakukan ni kannrensuru youin [Factors com- pelling family caregivers to commit physical or emotional abuse toward elderly persons requir- ing care]. Japanese Journal of Gerontology, 31(1), 21-31.

Oğlak, S. (2007). Uzun süreli evde bakım hizmetleri ve bakım sigortası, Türk Geriatri Dergisi, 10(2), 100-108.

Öz, F. (1998). Bağlaşıklık ve hemşirelik. Kriz Dergisi, 6(1). 67-73.

Proust, M. (2006). Sainte Beuve'e karşl, (Çeviren: R. Hakmen), Özgün Adı: Contre Sainte-Beuve, İstanbul: Doğu Batı Yayınları, 82.

Resmi Gazete (RG). (1963). Birinci beş yıllık kalkınma planı 1963 yıllık programı, 08.021963 , Sayı:11329. Ankara: Başbakanlık Mevzuat Geliştirme Dairesi Başkanlığı

Resmi Gazete (RG). (2005a). Evde Bakım Hizmetleri Sunumu Hakkında Yönetmelik, 10 Mart 2005. Ankara: Başbakanlık Mevzuat Geliştirme Dairesi Başkanlığı.

Resmi Gazete (RG). (2005b). Evde Bakım Hizmetleri Sunumu Hakkında Tebliğ, 13.09.2005; Sayı: 25935. Ankara: Başbakanlık Mevzuat Geliştirme Dairesi Başkanlığı.

Resmi Gazete (RG). (2008). Yaşlı Hizmet Merkezlerinde Sunulacak Gündüzlü Bakım ile Evde Bakım Hizmetleri Hakkında Yönetmelik. 07.08.2008, Sayı: 26960. Ankara: Başbakanlık Mevzuat Geliştirme Dairesi Başkanlığı.

Rosenbrock, R. (1998). Gesundheitspolitik., K. Hurrelmann ve U. Laaser (Editörler), Handbuch Gesundheitswissenschaften, Weinham, Germany: Juventa, 707-751.

Rothgang, H. ve G. (2007). Long term care in Germany. The Japanese Journal of Social Security Policy, 6(1). 54-83.

Ryder, C.F. (1960) Official and Voluntary Agencies, Public Health Reports (1896-1970), 75(12), 11351136.

Ryder Claire, F., Stitt Pauline, G. ve William, F.E. (1969). Home health services- past, present, future. American Journal of Public Health (AJPH), 59(9), 1720-1729.

Sağlık Bakanlığı (SB). (2010). Sağlık Bakanlığı tarafından Sunulan Evde Sağlık Hizmetlerinin Uygulama Usul ve Esasları Hakkında Yönerge, 1 Şubat 2010 tarih ve 3895 sayılı makam oluru. Ankara.

Santana, S. (2010). Reforming long- term care in Portugal: Dealing with the multidimensional character of quality. Social Policy and Administration, 44(4), 512-528.

Satzinger, W., Courté-Wienecke, S., Wenng, S. ve Herkert, B. (2005). Bridging the information gap between hospitals and home care services: Experience with a patient admission and discharge form. Journal of Nursing Management, 13(3), 257-264. 
Schiamberg, L. B. ve Gans, D. (2000). Elder abuse by adult children: An applied ecological framework for understanding contextual risk factors and the intergenerational character of quality of life. International Journal of Aging and Human Development, 50(4), 329- 359.

Schmid, H.(2005) The Israeli long- term care insurance law: Selected issues in providing home care services to the frail elderly. Health and Social Care in the Community, 13(3), 191-200.

Schulmerich, S.C. (1999). Public policy out of control: the home health care experience. Care Management Journals, 1 (4), 258-66.

Schuster, D.H., Schulz, M. ve Behrens, J. (2013). Before empowerment: residents' memories of the role of the housemother in diaconal residential care setting in Germany 1945-1995. Journal of Psychiatric and Mental Health Nursing, 20, 613-622.

Shang, X. ve Wu, X. (2011). The care regime in China: Elder and child care. Journal of Comparative Social Welfare, 27 (2), 123-131.

Simonazzi, A. (2009). Care regimes and national employment models. Cambridge Journal of Economics, 33, 211-232.

Stacey, C.L. (2005). Finding dignity in dirty work: The constraints and rewards of low- wage home care labour. Sociology of Health \& Ilness, 27(6), 831-854.

Stacey, C.L. ve Ayers, L.L. (2012). Caught between love and money. The experiences of paid family caregivers. Qualitative Sociology (Qual Sociol), 35, 47-64.

Statistisches Bundesamt (2018). Bildungsstand der Bevölkerung_Ergebnisse des Mikrozensus 2016. Wiesbaden: Statistisches Bundesamt.

Szebehely, M. ve Trydegard, G.B. (2012). Home care for older people in Sweden: A universal model in transition. Health and Social Care in the Community, 20(3), 300-309.

Thabethe, N. (2011). Community home-based care-a cost-effective model of care: who benefits? AIDS Care, 23(7), 787-791.

Thome, B., Dykes, A.K. ve Hallberg, R.I. (2003). Home care with regard to definition, care, recipient, care, content, and outcome: Systemetic literature review. Journal of Clinicial Nursing, 12, 860-872.

Tufan, İ., \& Yazıcı, S. (2009). Yaşlılıkta Kuşaklararası İlişkiler. Toplum ve Sosyal Hizmet, 20(1), 47-52.

Türkiye İstatistik Kurumu (TÜIK). (2014). Diş ticaret istatistikleri, Temmuz 2014, TÜIK Haber Bülteni, 16077, Web: http://www.tuik.gov.tr/PreHaberBultenleri.do?id=16077 adresinden 10.11.2014 tarihinde erişildi.

Tønnessen, S., Nortvedt, P. ve Førde, T. (2011). Rationing home-based nursing care: Professional ethical implications. Nursing Ethics, 18(3), 386-396.

Twigg, J. (2000). Carework as a form of bodywork. Ageing and Society, 20, 389-411.

U.S. General Accounting Office Center. (2001). Recruitment and retention of nurses and nurse aides is a growing concern. Web: http :// www.gao.gov / new. items / d01750t . pdf adresinden 14 Aralık 2009 tarihinde erişilmiştir.

Wardell, M. (1992) Organizations: A bottom-up approach. M. Reed, ve M. Hughes (Ed.). Rethinking Organizations: New Directions in Organizational Theory and Analysis içinde. London: Sage

Weissert, W.G., Matthews, C.C. ve Pawelak, J. E. (2005). The past and future of home- and communitybased long-term care. The Milbank Quarterly, 83(4), 1-71.

Wiener, M.J. ve Cuellar, A. E. (1999). Public and private responsibilities: Home and community- based services in the United Kingdom and Germany. Journal of Aging and Health, 11(3). 417-444.

World Health Organization. (2011). Palliative care for older people: better practices. S. Hall, H. Perkova, A. D. Tsouros, M. Costantini, I. J. Higginson (Ed.). Copenhagen: World Health Organization içinde (WHO) Regional Office for Europe. 
World Health Organization (WHO). (2012). Defusing the demographic "time-bomb" in Germany. Bulletin of the World Health Organization, 90 (1).

Yong, V. ve Saito, Y. (2012). National long-term care insurance policy in Japan a decade after implementation: Some lessons for aging countries. Ageing Int, 37, 271-284.

Yurtdışı Türkler ve Akraba Topluluklar Başkanlığı (2011) Avrupa'da yaşayan Türkler, yaz tatili döneminde Türkiye'ye gelen Türkler örneği saha araştırması, Ankara: T.C. Başbakanlık Yurtdışı Türkler ve Akraba Topluluklar Başkanlığı.

Zeytinoğlu, I. U., Denton, M., Davies, S. ve Plenderleith, J.M. (2009). Casualized employment and turnover intention: home care workers in Ontario, Canada. Health Policy, 91(3), 258-268. 